Depth of coma and the presence of abnormal plantar reflexes in the acute stage of poisoning were considered by Zahle (1948) to correlate with the development of neuropsychiatric sequelae, while Bokonjic (1963) determined that the duration of coma, the advancing age of the patient, and the development of cardiovascular failure indicated a poor prognosis for both survival and the recovery of mental functions. In the current study the level of consciousness on admission correlated with the development of gross neuropsychiatric sequelae, but the correlation with reflex abnormalities failed to reach a significant level; prolonged periods of delirium associated with poisoning and advancing age were not of prognostic significance, and only one patient had been in cardiac failure on admission. A relapsing course had occurred in one patient developing a dementing process. Oxygen therapy had been reserved for the more severely affected patients, so that the consequence of failing to administer oxygen could not be established, and the carboxyhaemoglobin levels had been estimated on too few patients to allow any conclusions. Subjective complaints and objective evidence of memory impairment were also related to the level of consciousness on admission.

The frequency of acute $\mathrm{CO}$ poisoning in Great Britain is sharply declining (Office of Health Economics, 1972), but the high mortality rate and the considerable morbidity in the survivors call for continuing efforts to prevent acute poisoning and to treat promptly those exposed. The lowering of the $\mathrm{CO}$ content of town gas has reduced the frequency of accidental and suicidal exposure (Gremy et al., 1968; Hassall and Trethowan, 1972), but inadequate ventilation and flueing of appliances burning natural gas can produce high levels of $\mathrm{CO}$ with fatal consequences (Ministry of Technology, 1970). Firemen may be exposed to black smoike, and the possibility that patients sustaining burns from fires in enclosed spaces may be suffering severe CO poisoning should always be considered (Pollard, 1970). The internal combustion engine is likely to continue as a source of exposure.

Our findings suggest that the hazards of $\mathrm{CO}$ poisoning are not always appreciated by casualty officers, and as it becomes less common the dangers of unfamiliarity are increased. In our view every patient exposed to $\mathrm{CO}$ should receive prompt and efficient oxygenation including hyperbaric therapy where available, and the early reduction of cerebral oedema with hypertonic solutions or steroids may be of value. The importance of providing follow-up facilities in the anticipation of a relapsing course or the delayed development of neuropsychiatric and cardiac sequelae has been established.

We wish to thank Mrs. P. Walker for her invaluable work in the tracing of patients, and all of our colleagues who helped in this tracing and made their clinical records available to us. The advice and assistance of Professor M. Roth on the conduct of the study and the editorial notes of Professor L. Kiloh are greatly appreciated. This study was supported by grants from the scientific and research committee of the Royal Victoria Infirmary and Pfizer Pty. Ltd.

Requests for reprints should be addressed to Dr. S. Brandon, Department of Psychiatry, Gaskell House, Swinton Grove, Manchester 13.

\section{References}

Bokonjic, N. (1963). Electroencephalography and Clinical Neurophysiology,

Cosby, R. S., and Bergeron, M. (1963). American fournal of Cardiology, 11,

Fields, F. R. J. (1971). Diseases of the Nervous System, 1, 673

Garland, H., and Pearce, J. (1967). Quarterly fournal of Medicine, 36, 445 Gremy, F., Salmon, D., Francois R.-C., and Bertin, M. (1968). Presse Medicale, 76, 1099.

Hadley, M. (1952). British Heart Fournal, 14, 534.

Hassall, C., and Trethowan, W. H. (1972). Suicide in Birmingham, vol. 1, p. 717 .

Hayes, J. M., and Hall, G. V. (1964). Medical fournal of Australia, 1, 865. Kuroiwa, Y., Shida, K., Nagamatsu, K., Kato, M., and Santa, T. (1967). Folia Psychiatrica et Neurologica faponica, 21, 189.

Meyer, A. (1963). In Greenfield's Neuropathology, 2nd edn. London, Arnold. Middleton, G. D., Ashby, D. W., and Clark, F. (1961). Lancet, 1, 12. Ministry of Technology (1970). Report of Inquiry into Safety of Natural Gas

Office of Health Economics (1972). Information Sheet, No. 18: Suicide. London, O.H.E.

Orinius, E. (1968). Acta Medica Scandinavica, 183, 239.

Pollard, J. A. (1970). British fournal of Surgery, 57, 635

Richardson, J. C., Chambers, R. A., and Heywood, P. M. (1959). Archives of Neurology, 1, 178.

Shafer, N., Smilay, M. G., and MacMillan, F. P. (1965). American fournal of Medicine, 38, 316.

Shillito, F. H., Drinker, C. K., and Shaughnessy, T. J. (1936 a). fournal of the American Medical Association, 106, 669.

Shillito, F. H., Drinker, C. K., and Shaughnessy, T. J. (1936 b). American Gas Association Monthly, 260.

Simpson, C. A. (1963-5). Newcastle Medical fournal, 28, 67.

Smith, J. S. And Brandon, S. (1970). Postgraduate Medical fournal, 46, 65 Smith, J. S., Brierley, H., and Brandon, S. (1971). Psychological Medicine, 1 172 .

Veil, C., et al. (1970). Annales Médico-Psychologiques, 2, 343.

Wilson, G., and Winkleman, N. W. (1924). Fournal of the American Medical Association, 82, 1407

Zahle, V. (1948). Kliniske Studie Med. Saerlig Henblik Paa Komplikationerne. Aarhus, Universitetsforlaget.

\title{
The Wounded Uterus: Pregnancy after Hysterotomy
}

\author{
W. M. CLOW, A. C. CROMPTON
}

British Medical fournal, 1973, 1, 321-323

\section{Summary}

Despite contraceptive advice, a high proportion of patients who have had a pregnancy terminated by hysterotomy became pregnant again within a short space of time. Fifty-three such pregnancies have been studied, and a substantial risk of rupture of the uterus was demonstrated in 14 cases where the scar was thin. Rupture, impending rupture, or presump-

St. Mary's Hospital, Manchester M13 0JH

W. M. CLOW, M.B., M.R.C.O.G., Clinical Tutor

A. C. CROMPTON, M.D., M.R.C.O.G., Lecturer, Department of Obstetrics and Gynaecology. (Present appointment: Consultant Obstetrician and Gynaecologist, St. James's University Hospiatl, Leeds.)

tive rupture occurred in three of these cases. Nevertheless successful vaginal delivery occurred in about $80 \%$ of cases. The infants so produced were often small for dates. Due weight should be given to the risks of subsequent early pregnancy and uterine rupture before terminating a pregnancy by the operation of hysterotomy without sterilization.

\section{Introduction}

Since the implementation of the Abortion Act in 1967 hysterotomy has been the method of termination adopted for about $25 \%$ of patients (Registrar General, 1970, 1971). Sood (1971), Stallworthy et al. (1971), and Brown et al. (1971) have shown that this method carries a high morbidity. Peel (1970) and Lewis (1969) suggested that the increased use of this operation, un- 
less associated with tubal ligation, will probably result in an increased incidence of rupture of the uterus in any subsequent pregnancy. This paper is concerned with the outcome of 53 pregnancies in patients who have a hysterotomy scar on the uterus.

\section{Patients and Methods}

A total of 53 pregnancies subsequent to termination of pregnancy by abdominal hysterotomy were studied in 45 patients. Twenty-six of these patients had the initial operation performed in St. Mary's Hospital, and 19 attended St. Mary's Hospital antenatal clinic though operated on elsewhere. Seven of the 53 pregnancies did not reach the third trimester as six were again terminated, five by abdominal hysterotomy and one by vaginal evacuation of the uterus; the seventh aborted spontaneously. The remaining 46 pregnancies in 38 patients resulted in 47 live births (including two sets of twins) and one stillbirth. The ages of the patients terminated varied from 12-38 years with a mean age of 21 years.

The pregnancies of 192 consecutive patients who were confined in this hospital in 1970, who had delivered a previous baby by caesarean section, were also studied. By exclusion of grand multiparous patients and those delivered by elective caesarean section, this group was reduced to one of 88 patients who were of similar age and parity to the hysterotomy series and in whom there was a possibility of vaginal delivery. The differences between these groups were assumed to be related to the different type of scar, or the special circumstances which justified hysterotomy.

\section{INDICATION FOR INITIAL HYSTEROTOMY}

Severe physical disease was present in three of the 45 patients studied, one patient had nephritis, one had cardiac disease, and one had a cerebral medulloblastoma. There were two patients who had abnormal pregnancies (a hydatidiform mole and a missed abortion). In four further cases there was thought to be a substantial risk that the fetus would be abnormal. The remaining patients suffered from reactive depression or other psychiatric disease. Thirty-nine of the pregnancies were conceived out of wedlock. Many of these factors were also present in the subsequent pregnancies, 27 of which were conceived out of wedlock.

\section{INTERVAL BETWEEN PREGNANCIES}

After the initial operation, contraceptive advice, encouragement, and warning of the hazards of subsequent pregnancy had been given to all the patients-especially those whose pregnancies were conceived out of wedlock. Despite this, 19 patients (42\%) were pregnant again within six months of termination, and $26(58 \%)$ were pregnant within one year of the initial operation. By way of comparison, when the group of patients who had been matched for age and parity became pregnant after a caesarean section for a non-recurring cause the interval between pregnancies was one year or less in only $30 \%$ of cases.

\section{ANTENATAL CLINICAL DATA}

The antenatal problems encountered are summarized in the table. Three patients were regularly taking addictive drugs. One of these patients also developed severe abruptio placentae and required a blood transfusion of eight battles. This resulted in the only stillbirth of the series. There were three other cases of antepartum haemorrhage. One of these infants died of pneumonia at the age of 7 weeks.
Clinical Data in the Cases under Study

\begin{tabular}{|c|c|c|c|c|}
\hline $\begin{array}{l}\text { Antenatal } \\
\text { Condition }\end{array}$ & $\begin{array}{l}\text { No. of } \\
\text { Cases }\end{array}$ & Management & $\begin{array}{c}\text { State of } \\
\text { Infant }\end{array}$ & Comments \\
\hline Addictive drugs ... & 3 & $\begin{array}{c}\text { Fetal growth } \\
\text { monitoring }\end{array}$ & $\begin{array}{l}1 \text { stillborn* } \\
2 \text { alivet }\end{array}$ & $\begin{array}{l}1 \text { live child below } \\
\text { 10th percentile } \\
\text { birth weight }\end{array}$ \\
\hline Abruptio placentae & 1 & $\begin{array}{l}\text { Blood transfusion } \\
\text { eight bottles. } \\
\text { Induction }\end{array}$ & Stillborn* & $\begin{array}{l}\text { Patient taking } \\
\text { LSD and } \\
\text { marijuana }\end{array}$ \\
\hline $\begin{array}{l}\text { Antepartum } \\
\text { haemorrhage of } \\
\text { uncertain origin }\end{array}$ & 3 & $\begin{array}{l}\text { Placental } \\
\text { localization. } \\
\text { Rest. Induction } \\
\text { before term }\end{array}$ & Alive & $\begin{array}{l}\text { One infant died } \\
\text { of pneumonia } \\
\text { aged } 7 \text { weeks }\end{array}$ \\
\hline $\begin{array}{l}\text { Twin pregnancy } \\
\text { (hydramnios in } \\
\text { one case) }\end{array}$ & 2 & Rest & 4 alive & $\begin{array}{l}3 \text { out of } 4 \text { infants } \\
\text { below 10th } \\
\text { percentile } \\
\text { birth weight } \\
\text { for twins } \ddagger\end{array}$ \\
\hline $\begin{array}{l}\text { Iron deficiency } \\
\text { anaemia }\end{array}$ & 3 & Oral iron & Alive & \\
\hline $\begin{array}{l}\text { Antepartum deep } \\
\text { venous thrombosis }\end{array}$ & 1 & Anticoagulants & Alive $\dagger$ & Elective L.S.C.S. \\
\hline $\begin{array}{l}\text { Rhesus isoimmun- } \\
\text { ization (and } \\
\text { antepartum } \\
\text { haemorrhage) }\end{array}$ & 1 & $\begin{array}{c}\text { Induction at } \\
37 \text { weeks }\end{array}$ & $\begin{array}{c}\text { Alive. } \dagger \\
\text { Exchange } \\
\text { transfusion }\end{array}$ & $\begin{array}{l}\text { Respiratory } \\
\text { distress } \\
\text { syndrome }\end{array}$ \\
\hline Urinary infection & 2 & Antibiotics & Alive $†$ & \\
\hline Ovarian cyst & 1 & $\begin{array}{l}\text { Ovariotomy, at } \\
12 \text { weeks' } \\
\text { gestation }\end{array}$ & Alive & \\
\hline Mild toxaemia $\ldots$ & 3 & $\begin{array}{l}\text { Induction at } \\
39-40 \text { weeks }\end{array}$ & Alive & \\
\hline $\begin{array}{l}\text { Prolonged } \\
\text { pregnancy (over } \\
41 \text { weeks) }\end{array}$ & 7 & $\begin{array}{l}4 \text { induced at } \\
41-42 \text { weeks }\end{array}$ & $\underset{1 \dagger}{\text { Alive }}$ & $\begin{array}{l}\text { L.S.C.S. } \times 2 \text { for } \\
\text { failed } \\
\text { induction }\end{array}$ \\
\hline
\end{tabular}

* Same patient.

† Infant's birth weight below 10th percentile (Tanner and Thomson, 1970).

$\ddagger$ Birth weight of 3 twins below 10th percentile (Professor B. Richards, personal communication, 1972)

\section{DELIVERY}

Nine infants were delivered by caesarean section, and 37 by the vaginal route.

Caesarean Section.-In two cases (described below) the caesarean section was performed because of an extremely dangerous scar; one of these scars ruptured. Three patients had an elective caesarean section, solely because of the presence of a "classical" type scar on the uterus. Two other patients failed to deliver vaginally after induction of labour for postmaturity by amniotomy and oxytocin infusion. One patient developed an intrauterine infection after prolonged rupture of the membranes, while the remaining patient was admitted at term with a shoulder presentation and ruptured membranes.

Vaginal Delivery.-Altogether, 37 vaginal deliveries (including two sets of twins) were achieved; 28 of these were delivered spontaneously. There were five low and three rotational forceps deliveries and one assisted breech delivery. Seven patients were induced for various reasons; five successfully. In the two cases where induction failed, oxytocin administration was intentionally restricted to a low dosage schedule.

The outcome of labour and mode of delivery in these patients followed an almost identical pattern to that found in the comparative series of patients who were pregnant after a caesarean section for a non-recurring cause.

\section{STATE OF HYSTEROTOMY SCARS AFTER SUBSEQUENT PREGNANCIES}

The scar was examined by inspection or palpation or both in 31 cases. It was thin in 14 cases, and also dangerous in the three cases described below. The remaining 17 scars were intact. There were three situations where the scar successfully stood up to excessive strain without rupture-namely, the two patients with twins and the patient with severe abruptio placentae. 
Patient $A$ had had an uneventful pregnancy but during the first stage of labour she developed epigastric pain, at first of an intermittent nature. This was associated with tenderness near the uterine fundus. The pulse and blood pressure remained within normal limits. At laparotomy bleeding was seen from a rupture at a point which corresponded to the upper limits of the previous hysterotomy scar. Placental tissue appeared to be invading the uterine muscle deeply at this point.

Patient $B$ was admitted at 34 weeks' gestation on account of abdominal pain. A clinical diagnosis of early uterine rupture was made on account of scar tenderness, tachycardia, anxious expression, and sweating. At laparotomy the scar was intact, but paper-thin along its length. The live infant was delivered by lower segment caesarean section, and the thin scar was excised and repaired in three layers.

Patient $C$ was admitted in early hesitant labour, and delivered spontaneously 29 hours later. An attempt was made to assess the scar vaginally with limited success, but no defect was palpated. About an hour after delivery there was slight vaginal bleeding and a few clots of blood were expelled. A few hours later she developed central abdominal pain, tachycardia, and a mild pyrexia. These signs and symptoms were attributed to infection, treated with antibiotics, and they subsided within 36 hours. On the third day her haemoglobin, which had been $14.3 \mathrm{~g} / 100 \mathrm{ml}$ just before admission, was found to have fallen to $8.6 \mathrm{~g} / 100 \mathrm{ml}$. A retrospective diagnosis of small uterine rupture was made. Since the patient did not want more children, laparoscopic sterilization was carried out six weeks later, when there was no evidence of inflammatory reaction in the pelvis and the presumed rupture appeared to have healed satisfactorily.

\section{INFANTS}

There were 46 live infants and the stillbinth. The weights of 14 babies $(30 \%)$ were below the 10th percentile, while seven $(15 \%)$ were below the 5th percentile. These infants were mostly regarded as dysmature, but one developed the respiratory distress syndrome and died of pneumonia at the age of 7 weeks.

\section{Discussion}

This group of patients appears to be highly fertile. Despite the active encouragement of contraception, at least 27 out of 86 patients $(30 \%)$ who were terminated in St. Mary's Hospital before 1971 have since become pregnant and, despite the fact that most pregnancies terminated by hysterotomy were conceived out of wedlock, the time intervals between pregnancies were noticeably shorter than those in the caesarean section group where a stable relationship was more often present.

The medical and social circumstances that constituted grounds for termination of pregnancy by hysterotomy often persisted in the subsequent pregnancies. Most of the hazards of the subsequent pregnancies, such as antepartum haemorrhage, drug addiction, and small-for-date babies, could have been a reflection of these factors.

There is a dilemma of management regarding induction of labour, since on the one hand $30 \%$ of infants are small for dates, while on the other the presence of a scar which is liable to rupture makes one reluctant to use oxytocin in any but limited dosage. This half-hearted induction leads to failed induction in a substantial number of cases.

It seems that the hysterotomy scar is as dangerous as the classical caesarean section scar since rupture or impending rupture occurred in three out of the 38 patients whose pregnancies reached the third trimester. The figure of 14 thin scars out of 31 examined approximately corresponds to the study of hysterographic records reported by Russell and Hewlett (1969). Nevertheless, safe vaginal delivery was achieved in 37 cases $(80 \%)$

The risks shown in this small group of patients exemplify Peel's (1970) concern regarding the wider implementation of the Abortion Act. In view of the youth of many of our patients, further pregnancies are probable in many cases with a continuing risk as the size of their babies increases. These risks must be added to those of the initial operation, and we feel they constitute grounds for eschewing the operation of termination of pregnancy by hysterotomy wherever possible.

We would like to thank Dr. R. H. Martin, of Wythenshawe Hospital, Dr. K. Rees, of Stepping Hill Hospital, Dr. O. V. Jones, of Bangor Hospital, and all the members of the consultant obstetric staff at St. Mary's Hospital, Manchester, who allowed us access to their patient's clinical records. In addition we would like to thank Professor W. I. C. Morris and Dr. D. W. Warrell, for their help and advice.

\section{References}

Brown, A. D. G. et al. (1971/2). Transactions of the Edinburgh Obstetrical Society, Session CXXIV, p. 2.

Lewis, T. L. T. (1969). British Medical fournal, 1, 241.

Peel, Sir J. (1970). In Year Book of Obstetrics and Gynaecology, ed. J. P. Greenhill, p. 29. Chicago, Year Book Publishers.

Registrar General (1970). Statistical Review of England and Wales for the Year 1968. Supplement on Abortion. London. H.M.S.O.

Registrar General (1971). Statistical Review of England and Wales for the Year 1969. Supplement on Abortion. London, H.M.S.O

Russell, A. J., and Hewlett, P. M. (1969). Fournal of Obstetrics and Gynaecology of the British Commonwealth, 76, 721.

Sood, S. V. (1971). British Medical fournal, 4, 270.

Stallworthy, J. A., Moolgaoker, A. S., and Walsh, J. J. (1971). Lancet, 2

Tanner, J. M., and Thomson, A. M. (1970). Archives of Disease in Childhood, 45, 566 . 